\title{
Perception on facilitators and benefits of participation in body practice groups
}

\section{Percepção sobre os facilitadores e os benefícios da participação em grupos de práticas corporais}

Caroline Maria Franke

(1) https://orcid.org/0000-0002-8698-640X

Moane Marchesan Krug

(D) https://orcid.org/0000-0002-1212-0400

Abstract - The practice of physical activity has been considered as an important factor in the area of public health, as it helps in the prevention and treatment of various diseases. Thus, understanding the facilitators for participation and benefits from healthy lifestyle can contribute to population awareness. The aim of this study was to analyze facilitators for body practice and benefits perceived by participants of body practice groups of two basic family health units of Santa Rosa/RS. This qualitative research included 25 participants. Data were obtained by the focal group technique. Motivation/incentive, mainly linked to family support, the pedagogical practice of the Physical Education professional, good health status and social life were aspects considered facilitators for adherence to body practice groups. Physical and psychological gains, prevention and control of diseases, lifestyle changes, cognitive improvement and decreased use of medications were pointed as benefits. Motivating participants to participate in body practice programs is an important factor for adherence and participation in these activities can provide biopsychosocial benefits that can contribute to health promotion and quality of life of users of basic family health units.

Key words: Motivation; Physical activity; Public health.

Resumo - A prática de atividade física vem sendo tratada como um fator importante na área da saúde pública, pois pode auxiliar na prevenção e no tratamento de diversas doenças. Para isso, entender sobre os facilitadores para a participação e os benefícios a partir de um estilo de vida saudável pode contribuir para a conscientização da população. Objetivou-se analisar os facilitadores para à prática corporal e os benefícios percebidos pelos participantes do grupo de prática corporal de duas unidades básicas de saúde da família de Santa Rosa/RS. Pesquisa qualitativa, com 25 participantes. Os dados foram obtidos pela técnica do grupo focal. Revelaram-se como facilitadores para a adesão a grupos de prática corporal a motivaçấo/ incentivo, ligado principalmente ao apoio familiar, a prática pedagógica do profissional de Educação Física, ser saudável e o convivio social. Foram apontados como benefícios ganhos físicos e psicológicos, a prevenção e controle de doenças, mudanças de estilo de vida, a melhora cognitiva e a diminuição do uso de medicamentos. Motivar os participantes dos programas de práticas corporais é um fator importante para a adesão aos grupos e a participação nessas atividades pode proporcionar benefícios biopsicossociais que podem contribuir com a promoção da saúde e na qualidade de vida de usuários de unidades básicas de saúde.

Palavras-chave: Atividade física; Motivação; Saúde pública.
1 Regional University of Northwestern State of Rio Grande do Sul. ljuí, RS. Brazil.

Received: January 20, 2019 Accepted: October 19, 2019

How to cite this article Franke CM, Krug MM. Perception on facilitators and benefits of participation in body practice groups. Rev Bras Cineantropom Desempenho Hum 2020, 22:e60330. DOl: http://dx.doi.org/10.1590/19800037.2020v22e60330

Copyright: This work is licensed under a Creative Commons Attribution 4.0 International License. 


\section{INTRODUCTION}

Active lifestyle has been recommended as an important factor for health promotion, as it can assist in the prevention and treatment of several diseases $^{1}$. However, despite the positive reports regarding the regular practice of physical activities, the prevalence of physical inactivity in Brazil is still high $^{2}$. Data from the 2016 Surveillance System of Risk Factors and Protection for Chronic Diseases by Telephone Survey (VIGITEL) show that $47.5 \%$ of individuals aged 18 or over are inactive or insufficiently active.

This high prevalence can be explained by technological evolution that has increased the use of screens such as television, computers, cell phones, and video games, and daily commuting using automobiles, escalators and elevators ${ }^{3}$.

In order to reduce the high prevalence of physical inactivity, the $\mathrm{Na}-$ tional Health Promotion Policy (PNPS), which aims to promote quality of life and reduce health risks, adopted as one of the eight priority themes, body practices / physical activity as a strategy to encourage the population to adopt a more active lifestyle ${ }^{4}$ by attending places that offer such activities ${ }^{5}$.

To achieve this goal, different governmental agencies have encouraged the creation of physical activities / body practices programs in primary health care based on the principles of the Unified Health System ${ }^{6,7}$, where practices are developed within the scope of Public Health.

In the city of Santa Rosa / RS, most Basic Family Health Units (UBSF) have body practice groups aimed at the general population, which in addition to providing physical activities according to territory, bring the proposal of education in health. However, in addition to providing groups, it is necessary to understand the reasons that lead users to participate in them, as well as the benefits arising from this practice.

It is known that these reasons are diverse and include knowledge about the benefits that active lifestyle can bring ${ }^{8}$. Therefore, knowing the benefits of active lifestyle is also a relevant factor to create bonds with users.

Many studies have been carried out to assess the facilitators of physical activity in children and adolescents ${ }^{9}$, adults ${ }^{10}$, elderly ${ }^{11,12}$, workers ${ }^{13}$ and those with intellectual deficits ${ }^{14}$. However, there are few reports found in primary care that come from the analysis of a focus group (FG).

Thus, the present study aimed to analyze facilitators for body practice and benefits perceived by participants in body practice groups of two UBSFs of Santa Rosa / RS.

\section{METHOD}

This is a qualitative, descriptive and comparative study that used the qualitative health research guide (RATS Guidelines) for its design ${ }^{15}$.

Study participants were users of two UBSFs of Santa Rosa / RS. These health units were intentionally selected because they showed sociodemographic differences, in addition to being groups in which one of 
the researchers worked as a resident of the Multiprofessional Residency Program in Family Health.

All participants of body practice groups of both UBSFs were invited to participate in the study, named by UBSF A $(\mathrm{n}=10)$ and UBSF B ( $\mathrm{n}$ $=25)$, excluding those aged under 18 years $(n=1)$, those with cognitive impairment that prevented them from answering questionnaires $(n=1)$ and those who did not have regular frequency $(75 \%)$ in the group two months prior to the data collection period $(n=8)$. No one refused to participate in the survey.

Data collection was carried out in the months of October and November 2017, and the FG technique was used, which is an instrument used to conduct interviews in groups with the aim of collecting information that would help understanding the perceptions of a given theme in a specific group $^{16}$. Three FGs were held, one in the parish hall of the church next to UBSF A, with 7 participants, and two in a reserved room at UBSF B, each group with 9 participants. UBSF B was divided into two groups so as not to exceed the limit number of participants recommended in the FG technique; however, its analysis was conducted as a single group.

The developed script was based on the reflection of factors that encourage participation in activities proposed in groups; perception of difference or gain from participating in the group and motivation to continue participating in the group.

FG meetings were conducted by a researcher experienced in this data collection technique. Previously, training was carried out with this researcher and also a pilot study in another UBSF in another region of the city. Meetings were recorded in audio and filmed for later literal data transcription. After transcription, information was read to participants for the purpose of checking and interpreting speeches.

FG information was interpreted by content analysis ${ }^{17}$ carried out by the researcher who conducted meetings, who had no personal or professional relationship with research participants. Categories (benefits from body practice and facilitators for body practice) were created a priori and subcategories were created by systematic and objective procedures to describe the content of messages in an inductive manner after the reading of the entire transcript (pre-analysis), grouping of responses that allowed the inference of knowledge about the messages (exploration of the material) and subsequent categorization based on the researcher's knowledge on the subject (treatment of results). Participants were identified with a code (UA1, UA2 ... for UBSF A users and UB1, UB2, UB3 ... for UBSF B users).

Sociodemographic and health characteristics of study participants were also collected through questionnaire with closed questions that were analyzed using descriptive statistics (frequency).

The research was approved by the Teaching and Research Center of the Municipal Health Foundation and by the Research Ethics Committee of the Regional University of Northwestern State of Rio Grande do Sul (protocol No. 2.114.809 / 2017). 


\section{RESULTS}

The first results are related to the sociodemographic characteristics of study participants and can be seen in Table 1 . The study included 25 UBSF users who attended physical activity / body practice groups of UBSFs, 7 UBSF A users and 18 UBSF B users.

Table 1. Sociodemographic and health characteristics of participants in the physical activity / body practice groups of UBSFs of Santa Rosa / RS, 2017.

\begin{tabular}{lcc}
\hline Variables & $\begin{array}{c}\text { UBSF }(\mathrm{n}=7) \\
\mathrm{n}\end{array}$ & $\begin{array}{c}\text { UBSF B }(\mathrm{n}=18) \\
n\end{array}$ \\
\hline Sex & 2 & 3 \\
$\quad$ Male & 5 & 15 \\
\hline Female & & \\
Marital Status & 0 & 1 \\
\hline Single & 6 & 15 \\
\hline Married & 0 & 1 \\
\hline Divorced & 1 & 1 \\
Windowed & & 1 \\
Schooling & 0 & 12 \\
\hline Illiterate & 5 & 4 \\
\hline Elementary school & 1 & 1 \\
\hline High school & 1 & 5 \\
\hline Higher education & & 12 \\
\hline Economic condition & 4 & 1 \\
\hline High & 3 & \\
\hline Medium & 0 & \\
\hline Low & & \\
\hline
\end{tabular}

Facilitators for adherence to physical activity / body practice programs are shown in table 1 . Regarding factors that contributed for users to adhere to the program, factors such as motivation / incentive, the pedagogical practice of the Physical Education professional, good health status and social life stood out.

Regarding the benefits perceived by participants of physical activity / body practice groups, it was possible to identify differences in responses between units, which can be seen in box 2 .

\section{DISCUSSION}

In both groups, the majority of users were female aged over 54 years, married and with complete elementary school. At UBSF A, participants were of high economic status and at UBSF B, participants were mostly classified as middle economic class. These findings are in agreement with data obtained by Ferreira et al. ${ }^{18}$, who studied UBSF users in the municipality of Campo Grande / Mato Grosso and found that they were mostly women aged 50-69 years. With regard to schooling and marital status, data agree with results obtained by Lovato et al. ${ }^{19}$ with UBSF users in Londrina / Paraná. 
Box 1. Facilitators by practice in the physical activity/body practice group of both UBSFs of Santa Rosa/RS, 2017.

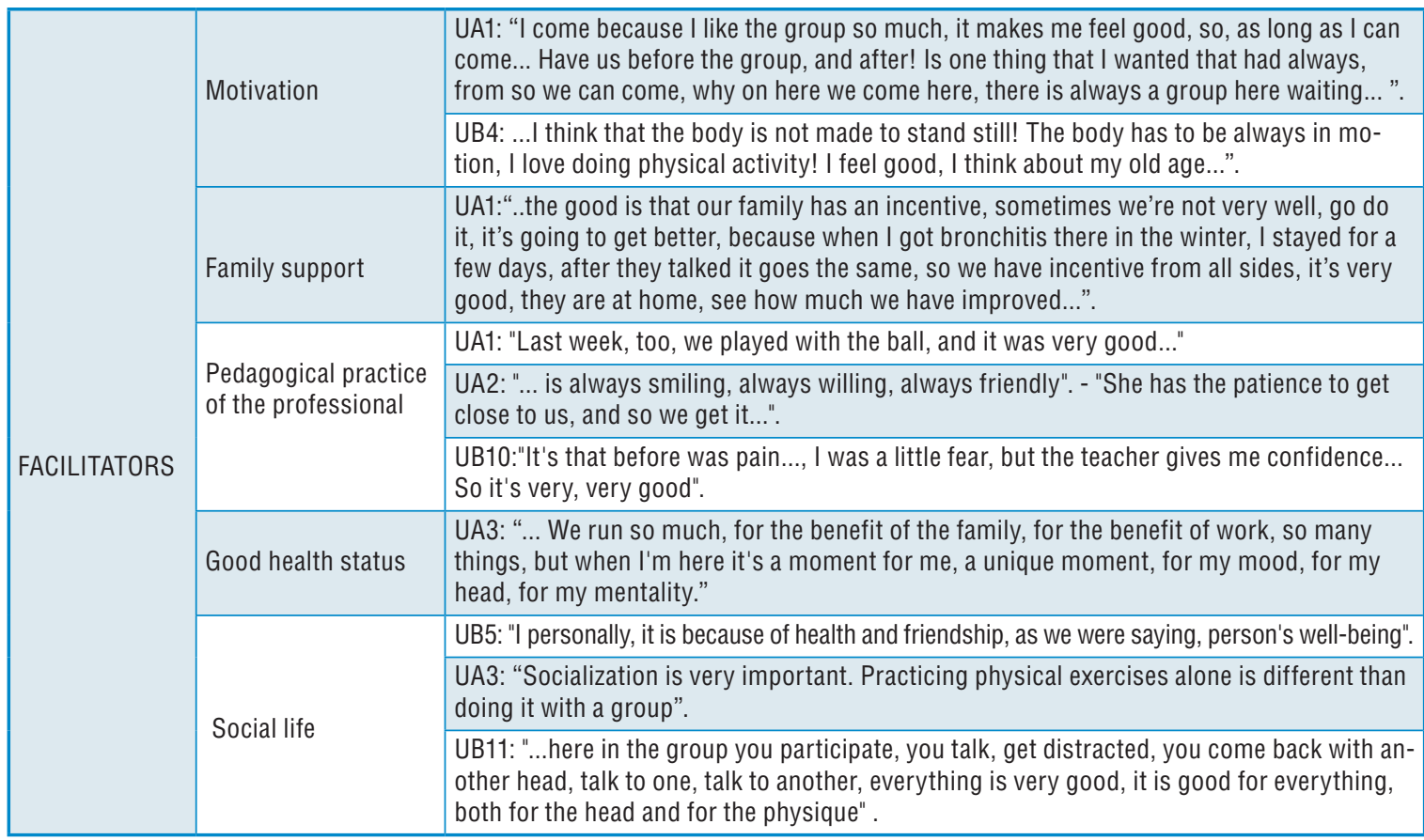

Box 2. Benefits perceived by the participants after participating in the physical activity/body practice group of UBSFs of Santa Rosa/RS, 2017.

\begin{tabular}{|c|c|c|}
\hline & & $\begin{array}{l}\text { UA2: "I have tendonitis in my arms, so before I couldn't even lift my arm to put on clothes, } \\
\text { now I lift and do gymnastics". }\end{array}$ \\
\hline & & $\begin{array}{l}\text { UB14: It was good for me, I already had hard body, today it is good for walking and today it } \\
\text { is good, I am always walking, I helps a lot". }\end{array}$ \\
\hline & Physical & $\begin{array}{l}\text { UB12: "The difference that I perceive with gymnastics, is that I now have the courage to cross } \\
\text { the street, because I did not have the courage, because I was afraid of locking my leg, it locked, } \\
\text { because this nerve is sick, it got the injury and it will stay, so we have to work, exercise and } \\
\text { strengthen this muscle! I was afraid of having to take a step from there, then I would stop ". }\end{array}$ \\
\hline & & $\begin{array}{l}\text { UA1: "I also came here invited by my psychologist, at the time I was also depressed, I } \\
\text { couldn't walk on the street alone, so I wasn't really well. Then he suggested a gift to me, I } \\
\text { accepted, then I came in the group, I never stopped, I liked much, it helped much, today I } \\
\text { am another person, I am happy, help for memory, I don't have time to think nonsense...". }\end{array}$ \\
\hline & Psychological & $\begin{array}{l}\text { UB3: “... I had been taking medication for depression for years... and now after I started } \\
\text { doing physical exercises, I improved a lot" }\end{array}$ \\
\hline BENEFITS & & $\begin{array}{l}\text { UB4: "Physical activity also prevents depression, it gives people a boost, a good mood, it's } \\
\text { all good, it releases endorphins". }\end{array}$ \\
\hline & & $\begin{array}{l}\text { UA6: "I felt much better after I started, blood pressure didn't increase anymore, before I lived } \\
\text { with high blood pressure, after I started, pressure improved a lot, and physically improved". }\end{array}$ \\
\hline & Control and prevention & UB3: "My pressure it was always high, now it's always good, you see how good the physics are". \\
\hline & & $\begin{array}{l}\text { UB5: "I used a medication for this disease that I have, its a very high infection, in the blood, } \\
\text { but with physical activity, the doctor said that this is what I help. Ankylosing spondylitis..." }\end{array}$ \\
\hline & Changes in lifestyle & $\begin{array}{l}\text { UA1: "I won very much in health, a lot, I say, today I am another person, after the participating } \\
\text { in gymnastics, I improved a lot, I stayed more healthier today, in food, we learned to take bet- } \\
\text { ter care, it's something that I change, so much that I think not would be without gymnastics". } \\
\text { UA3: "... I am always researching, this encourages, for example, if I come here, an exercise } \\
\text { then I will research something else of localized exercise, or one, about healthy eating". }\end{array}$ \\
\hline & Cognitive & $\begin{array}{l}\text { UB7: "I perceived a lot, that has evolved very much! We wanted to come, do physical, } \\
\text { because this is good for the body, and good for the mind, at least you remember that you } \\
\text { have to do things ...". }\end{array}$ \\
\hline & & $\begin{array}{l}\text { UB10: "Do you believe me 20, 30, } 40 \text { years old or more living in Santa Rosa, I once went } \\
\text { downtown, and I got lost, really?! I wanted to go to the Dom Bosco hospital and I took } \\
\text { another street and went and went down, I think, damn where am I? Something like that, give } \\
\text { me a white and not now, it was after gymnastics everything is good". }\end{array}$ \\
\hline
\end{tabular}


The fact of having more women in groups can be explained by the cultural process, where women tend to take more care of their health and their body ${ }^{11}$, which justifies participation in public health actions, and increased search for health care services.

The first facilitator who emerged during the interview was motivation. It appeared in different contexts, standing out as a motivation for the group, for the family, for enjoying participating in the group and for the expected / achieved results after participating in the group.

The aforementioned data are of great relevance, as motivation is a determining factor for choosing the way we live and feeling motivated, and belonging to a group helps in the process of adopting a more active lifestyle. In the study carried out by Lovato et al. ${ }^{19}$, positive results were found associating identity and feeling belonging to a group regarding frequency in physical activity programs.

Another facilitator revealed in speeches during the focus groups included in motivation was to enjoy and feeling pleasure with physical activities, as found in other studies ${ }^{20,21}$. When studying older adults from Antônio Carlos / Santa Catarina, Krug et al. ${ }^{20}$ reported that if subjects do not enjoy practicing physical activities, they will have difficulty in adhering to a physical exercise program.

Motivation was also reported associated with family support and incentive, showing the importance of this incentive for participation in groups. Family support as an incentive for the practice of physical activity was found in other studies ${ }^{11,12,20}$. Elderly people reported that incentive from family to practice in group activities, leisure and physical activities was an important facilitator ${ }^{11,12}$.

Another facilitator for adherence to physical practices / physical activity groups identified in this study was the pedagogical practice of the Physical Education professional, who coordinates and guides activities. Some participants highlight the professional's role in the group, in accepting individual difficulties, in conducting the group with motivation and enthusiasm and with creativity to diversify activities, making the group more attractive and pleasurable.

The skills of the Physical Education professional are highlighted as important reasons for people to remain in physical activity / body practice groups. In the study by Lopes et al. $^{12}$, with long-lived elderly women, it was reported that having a good professional in conducting activities, always encouraging and paying attention to the execution of exercises, makes a difference in adhering to a physical activity program.

Similar results were also found in other populations, as in the study by Boutevillain et al. ${ }^{21}$, who researched people with complaints of chronic low back pain and found that encouragement and correction during the execution of exercises as well as the skills of the Physical Education professional are determining factors for adherence.

It is important to emphasize that the Physical Education professional who works in public health needs to have a more humanized view of users. 
According to Freitas et al. ${ }^{22}$, the professional must have an understanding on the human being, know beyond his physical condition and give importance to subjectivities, leaving aside the academic mechanistic model.

Concerned with the academic model, curricula have been broadly conceived, with academic training focused on multiprofessional care, integrating Physical Education in the health area. In the last decades, Higher Education Institutions have been adapting their Physical Education curricula to meet the needs of today's society ${ }^{23}$.

It is also worth mentioning the importance of healthcare training for Physical Education professionals, since it is proven that lifestyle in childhood interferes in adulthood, and teachers can make a significant contribution for the development of healthier lifestyles both in children and adolescents ${ }^{24}$.

Another facilitator, which seems to be a category, is the individual concern with health, becoming a healthy person, valuing the practice of physical activity and its relationship with physical and mental health.

It is a consensus that physical exercise is good for health ${ }^{1,8}$. The concern with being healthy is one of the main facilitators that lead people to seek the practice of physical activities ${ }^{12,21}$. The study by Seron et al..$^{25}$ showed that this reason (being good for health) was also one of the main facilitators for the adherence to the practice of physical activities by people with motor disabilities (reported by $72 \%$ of study participants), followed by the desire of being an athlete and medical indication. Reinforcing the health reason as one of the main facilitators reported for adhering to physical activity, another study ${ }^{26}$ carried out with members of a workplace gymnastics program in companies indicated that $76.16 \%$ of participants reported participating in the program to improve health.

To complete facilitators, the last category presented in speeches is Social Life, which appeared repeatedly in the study, in which participants reported as one of the main reasons for participation in the group.

Accordingly, many studies have pointed out the practice of physical activity as a tool for socialization, especially in studies involving the elderly, in addition to physical benefits obtained from exercise, there are also reports of older adults seeking physical activity programs due to benefits for health and socialization. Studies highlight the importance of human relationships in health, in the exchange of experiences reported in these moments, and especially in the construction of social relationships ${ }^{12,21}$.

At UBSF A, physical and psychological benefits, prevention of diseases and lifestyle change were highlighted by participants. At UBSF B, physical, psychological and cognitive benefits were evidenced, as well as disease prevention and control and decrease in medication use.

In the reports of participants, some physical benefits in both UBSFs stood out, such as decreased pain, improved joint mobility and muscle strengthening.

In the study by Lopes et al. ${ }^{12}$, reports similar to those of the present study were observed, since the sample reported that when physical activities are not performed, body pain returns, and that the practice of exercises is a preventive factor. Another study also pointed out decrease in pain, especially 
in cases of varicose veins and mobility, associated with physical benefits ${ }^{27}$.

In the study by Aily et al. ${ }^{26}$, women aged over 60 years reported insecurity with their own bodies and fear of falling as barriers to the practice of physical activity.

The main psychological benefit reported by participants was the improvement in depression symptoms, especially for people who had already been diagnosed with depression and were on drug treatment, and those who started with only depressive symptoms reported improvement in their daily mood, and these reports were similar among participants of both UBSFs.

These results can be explained by the fact that during the practice of physical exercise, there is an increase in the release of monoamines (serotonin, dopamine and norepinephrine), which cause a feeling of well-being and improved mood, which may also be associated with relaxation from muscle excitation $^{28,29}$.

In the same sense, Deslandes ${ }^{29}$ mentions that physical exercise can help reducing depression symptoms when associated with pharmacological treatment, as it increases cortical activity. In addition, social interaction during group participation may have helped reducing depressive symptoms, because at that moment, users do not feel lonely ${ }^{12}$.

Regarding control and prevention of diseases as a benefit obtained through the practice of physical activity, the following speeches come into agreement between groups, mainly in their perception in relation to the control of blood pressure (BP):

It is already known that blood pressure can be regulated with physical exercise. The benefits can be obtained both in the acute effect of physical exercise and in a chronic way, after exercise. Thus, physical exercise is considered one of the main regulators of blood pressure ${ }^{30}$.

In the FG of UBSF A, a different benefit mentioned by participants was reported, change in lifestyle, especially with regard to eating habits.

Changes in lifestyle are beneficial for health, and when perceiving changes in their health related to healthy lifestyle, individuals start to consider other changes, that is, the practice of regular physical activity influences other healthy habits such as changes in eating habits ${ }^{11}$.

Cognitive effects, especially on memory, were reported only by the UBSF B group, and this result was due to the fact that this is group of people with average age of 60 years, but the majority of participants are older than that.

The decrease in the use of medications reported by the UBSF B group is highlighted, mainly related to pain due to the lack of physical exercises, which leads us to conclude that this population was more dependent on the use of medications.

Regular physical activity is considered a non-medication treatment for several chronic diseases and its regular practice, when properly oriented and regularly followed, can decrease the number of medications and hospitalizations ${ }^{29}$. In addition, regular physical activity is directly related to the decrease of body pain perception ${ }^{12,19}$. 
It is necessary to take into account that these benefits are subjective and reveal the importance of continuing activities, considering that effects were positive. In this sense, extrapolating the results of this study should be performed with caution because participants already attended UBSFs; therefore they are more concerned with health. Thus, studies should be carried out with older adults who are physically inactive and who do not attend UBSF. As a strong point of the study, analysis carried out in a qualitative way stands out and shows the perception of subjects regarding the practice of physical activity and the fact that it is a study that shows the importance of Physical Education professionals in basic healthcare.

\section{CONCLUSION}

In view of the results found in this study on facilitators for adherence to physical activity / body practice groups, it was observed that there is greater adherence of users when they are motivated / encouraged both by family members and by a qualified professional, as well as the feeling of belonging to a group through socializing with other members, and being concerned with their own health. It is worth mentioning the role of the Physical Education professional as a facilitator for the approach of this subject with the group, looking at individuals with their subjectivities considering physical, mental and social aspects.

The physical, psychological, cognitive, disease control and prevention benefits, lifestyle changes and reduction in the use of medicines were perceived by participants, proving that health promotion is much more effective when there is a professional conducting these reflections and placing the subject as the protagonist of his self-care.

For a broader view within physical activity / body practice groups, the training of professionals in the health area must include aspects that go beyond biological ones. Thus, Multiprofessional Residency programs are a good way to enhance training, aiming at expanded care, and providing experiences with professionals from other areas, which would add knowledge to be transmitted within the individual practice.

\section{Acknowledgments}

We would like to thank the Municipal Health Foundation of Santa Rosa (FUMSSAR) and also the Teaching and Research Center (NEP FUMSSAR) for the support in the construction of scientific knowledge as well as the opportunity and valuation of the work in Primary Health Care. We also thank the Regional University of Northwestern State of Rio Grande do Sul (UNIJUÍ), for the opportunity to develop a teaching relationship by applying scientific knowledge in work practice, as well as the availability of teachers / tutors in the Multiprofessional Residency program in Family Health in the transmission of knowledge during activities, and in particular, the Ministry of Health for granting the scholarship during the months of Multiprofessional Residency in Family Health. 


\section{COMPLIANCE WITH ETHICAL STANDARDS}

\section{Funding}

This study was developed with the authors' own funding

\section{Ethical approval}

The research followed recommendations of Resolution 466/2012, of the National Health Council and the methodological procedures were approved by the Teaching and Research Center of the Municipal Health Foundation of the municipality and by the Research Ethics Committee of the Regional University of Northwestern State of Rio Grande do Sul (protocol No. 2,114,809 / 2017).

\section{Conflict of interest statement}

The authors have no conflict of interests to declare.

\section{Author Contributions}

Conceived and designed experiments: CMF; MMK. Performed experiments: CMF; MMK. Analyzed data: CMF. Contributed with reagents/ materials/analysis tools: CMF; MMK. Wrote the paper: CMF; MMK.

\section{REFERENCES}

1. Lee IM, Shiroma EJ, Lobelo F, Puska P, Blair SN, Katzmarzyk PT. Effect of physical inactivity on major non-communicable diseases worldwide: an analysis of burden of disease and life expectancy. Lancet 2012;380(9838):219-29.

2. Brasil. VIGITEL Brasil 2015: Vigilância de Fatores de Risco e Proteção para Doenças Crônicas por Inquérito Telefônico. Brasília: Ministério da Saúde: Secretaria de Vigilância em Saúde; 2016.

3. Freire RS, Fonseca Filho JA, Nepomuceno MO, Silveira MF1. Prática regular de atividade física: estudo de base populacional no norte de Minas Gerais, Brasil. Rev Bras Med Esporte 2014, 20(5): 345-349.

4. Brasil. Ministério da Saúde. Portaria no 2.446 , de 11 de novembro de 2014. Redefine a Política Nacional de Promoção da Saúde (PNPS). Diário Oficial da República Federativa do Brasil, Brasília (DF), 2014.

5. Malta DC, Silva MMA, Albuquerque GM, Amorim RCA, Rodrigues GBA, Silva TSS, et al. Política Nacional de Promoção da Saúde, descrição da implementação do eixo atividade física e práticas corporais, 2006 a 2014. Rev Bras Ativ Fis Saude 2014;19(3):286-99.

6. Becker LA, Gonçalves PB, Reis RS. Programas de promoção da atividade física no Sistema Único de Saúde brasileiro: revisão sistemática. Rev Bras Ativ Fis Saude 2016;21(2):110-22.

7. Carvalho FFB. Práticas corporais e atividades físicas na atenção básica do sistema único de saúde: ir além da prevenção das doenças crônicas não transmissíveis é necessário. Mov 2016; 22(2):647-58.

8. Bauman AE, Reis RS, Sallis JF, Wells JC, Loos RJ, Martin BW. Correlates of physical activity: why are some people physically active and others not? Lancet 2012;380(9838):258-71.

9. Souza DL, Castro SBE, Vialich AL. Barreiras e facilitadores para a participação de crianças e adolescentes em um projeto socioesportivo. Rev Bras Ciênc Esporte 2012; 34(3):761-74. 
10. Souza TF, Santos SFS, José HPM. Barreiras percebidas à prática de atividade física no nordeste do brasil. Pensar Prát 2010;13(1):115-120.

11. Krug RR, Barbosa AR, Monego EA, Mello ALSF, França VF. The perception of the older adults regarding the practice of physical activity and healthy eating. Salud UIS 2015;47(2): 115-24.

12. Lopes MA, Krug RR, Bonetti A, Mazo GZ. Fatores influenciadores para adoção de prática de atividades físicas percebidos por pessoas longevas. Rev Educ Fís/ UEM 2014;25(2).

13. Grande AJ, Silva VAV. Barreiras e facilitadores para a adesão à prática de atividade física no ambiente de trabalho. Mundo Saúde 2014;38(2):204-9.

14. Jung LG, Kalinoski AX, Marques AC. Barreiras e facilitadores para a atividade física em pessoas com déficit intelectual. Rev Bras Ativ Fís Saúde 2017;22(4):362-72.

15. The Rats Guidelines modified BioMed central are copyright Jocalyn Clark, BMJ. They can be found in Clark JP. How to peer review a qualitative manuscript. In: Peer review in Health Sciences. Second edition. Edited by Goodle F, Jeferson T. London: BMJ Books, 2003, 219-235.

16. Trad LAB. Grupos focais: conceitos, procedimentos e reflexões baseadas em experiências com o uso da técnica em pesquisas de saúde. Physis 2009;19(3):777-96.

17. Minayo MCS. O Desafio do conhecimento: pesquisa qualitativa em saúde. 14 ed. Editora Hucitec, São Paulo, SP 2008.

18. Ferreira JS, Diettrich SEC, Pedro DA. Influência da prática de atividade física sobre a qualidade de vida de usuários do SUS. Saúde Debate 2015;39(106):792-801.

19. Lovato NS, Loch MR, González AD, Lopes MLS. Assiduidade a programas de atividade física oferecidas por Unidades Básicas de Saúde: o discurso de participantes muito e pouco assíduos. Rev Bras Ativ Fís Saúde 2015; 20(2):184-92.

20. Machin R, Couto MT, Silva GSN, Schraiber LB, Gomes R, Figueiredo WS et al. Concepções de gênero, masculinidade e cuidados em saúde: estudo com profissionais de saúde da atenção primária. Ciên Saúde Colet 2011;16:4503-12.

21. Boutevillain L, Dupeyron A, Rouch C, Richard E, Coudeyre E. Facilitators and barriers to physical activity in people with chronic low back pain: A qualitative study. Plos One 2017;12(7):1-16.

22. Freitas FF, Carvalho YM, Mendes VM. Educação física e saúde: aproximações com a "Clínica Ampliada”. Rev Bras Ciênc Esporte 2013; 35(3):639-56.

23. Fraga AB, Carvalho YM, Gomes IM. Políticas de formação em educação física e saúde coletiva. Trabalho Educ Saúde 2012;10(3):367-86.

24. Alberto AAD, Figueira Jr AJ. Percepções de determinantes bioculturais da atividade física e associação com características pessoais e profissionais de professores de educação física. Rev Bras Ciênc Esporte 2016;38(3):275-82.

25. Seron BB, Arruda GA, Greguol M. Facilitadores e barreiras percebidas para a prática de atividade física por pessoas com deficiência motora. Rev Bras Ciênc Esporte 2015;37(3):214-21.

26. Aily JB, Carnaz L, Farche AC, Takahashi AC. Perception of barriers to physical exercise in women population over 60. Motriz: J Phys Ed 2017;23(2):1-6.

27. Krug RR, Marchesan M. Percepções de mulheres idosas de Forianópolis/SC sobre a prática de atividades físicas no lazer. Rev Ciên Saúde 2012;31(1):55-64.

28. Santos CM, Barros SSH, Del Duca GF. Atividade física e depressão. In: Del Duca GF, Nahas MV. Atividade Física e doenças crônicas: evidências e recomendações para um estilo de vida ativo. Londrina: Midiograf, 2011.

29. Deslandes A. The biological clock keeps ticking, but exercise may turn it back. Arq Neuro-Psiquiat 2013;71(2):113-18..

30. Naci H, Ioannidis JPA. Comparative effectiveness of exercise and drug interventions on mortality outcomes: metaepidemiological study. BMJ 2013;347:f5577.

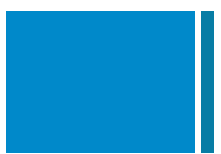

Corresponding author

Caroline Maria Franke

Rua Coronel Gervásio, 410, centro, Tapera / RS, Brasil.

Email: carolinemariafranke@hotmail.com 